\title{
THE CLASSICAL ASSOCIATION OF SOUTH AFRICA, 1908 - 1956
}

\author{
W J Henderson (University of Johannesburg)
}

This report on the existence and activities of the Classical Association of South Africa which have recently come to light (in the case of the 1908-1910 CASA) or more prominently to the fore (in the case of the 1927-1956 Association), is a prequel to earlier ones for the period 1956 to $1981 .^{1}$ The present account is based mainly on a Minute Book for the Stellenbosch Branch of the Classical Association of South Africa, which was founded in August 1927, was active until September 1935, was resucitated in May 1952 and, despite sporadic efforts to keep it alive, was defunct by 1955 . As in the case of its predecessors, this report concentrates on the people who were involved with the Association and thus deserve recognition, and also on the structures, activities and spirit that preceded and also left their mark on the later Association.

\section{Introduction}

Professor Richard Whitaker's two recent notes on a Classical Association of South Africa (CASA) that existed in 1908-1910 and thus predated the association which was constituted in 1956 as 'the first national conference' have necessitated a revision of the history of the Association. ${ }^{2}$ There was also a CASA during the years 1927-1956, until now considered the 'first', but henceforth to be regarded as the 'second'. Very little has been written about and not much interest shown in this second association, probably because of lack of information, most of it buried in archives or lost.

At the CASA Conference at the University of Pretoria in 2009, Professor Christoff Zietsman, then Chairperson of CASA, handed me a box of files for the CASA Archives. The box contained files and documents accumulated in the Departments of Latin and Greek at Stellenbosch University by previous officebearers. Among the documents, which cover the years 1956 to 2002, I found, hidden in a clip-file together with other documents, a large foolscap-size exercise book containing the minutes of meetings of 'The Classical Association of Stellenbosch (being a branch of the Classical Association of South Africa)'. The first entry started with the words: 'Inaugural Meeting. Tuesday, 9th August, 1927' and referred to the 'recently constituted Classical Association of South Africa', of which the Stellenbosch association was a branch. The recorded minutes go as far as 14 September 1935, resume on 20 May 1952 and end on 29 October 1953 - three

\footnotetext{
1 Henderson 2004, 2005, 2006, 2007, 2008.

$2 \quad$ Whitaker 2011 and 2012.
} 
years before the revived Association. Also included at the back of the Minute Book was a bundle of postcards, notices of meetings, correspondence, two published reports on the new CASA, and the minutes of the Greek section of the Stellenbosch branch, from 19 September 1927 to 24 October 1928, written on both sides of four foolscap pages. The latter was accompanied by a letter dated 18 June 1948, from Prof C Rose-Innes of the University of Cape Town, explaining that he had found the four pages 'in a scrap-book' in his office. He explained: 'How they got there I haven't the faintest idea, and am sending them along in case they are of some value to your records'. To preserve the chronological sequence, I have worked all these documents into this account of the minutes of meetings. There were four kinds of meetings recorded in these documents: the General Meetings of the national Classical Association of South Africa; and the General (i.e. combined Greek and Latin) and separate Latin and Greek meetings of the Classical Association of Stellenbosch.

Prof Smuts made use of this 'old Minute Book', often referring to it in his three important articles on the history of Classical studies in South Africa. I shall be examining it in greater detail in this article. My main focus will be on the activities of the Stellenbosch Association and the teachers of Classics, both at school and university level, who played an active role in the life of this branch, as recorded in the Minute Book. The broader purpose of this article is to begin to fill in the gaps in our knowledge of this period in the development of the Classical Association of South Africa.

\section{The development of the universities, 1829-1921}

To establish some of the context before we examine the Minute Book, it is advisable to refresh memories concerning the development of the South African universities. The period from the second British occupation of South Africa in 1806 to the 1920s saw the establishment and steady development of institutions of higher learning. ${ }^{3}$ In Cape Town there were two: the South African College (SAC, also called the Athenaeum) and the University of the Cape of Good Hope (henceforth the Cape University). The SAC, founded in 1829, was a teaching university, providing education at primary, secondary and post-matriculation levels. Between 1829 and 1843 student numbers at the SAC had declined from 115 to 20, and financial constraints limited the number of professors to three: two (one English and one Dutch) for Classics and one for Mathematics. The incumbents were three Reverends, E C Judge, A Faure and J Adamson respectively. ${ }^{4}$ These

3 For the creation of Secondary Schools, from many of which universities developed, see McKerron 1934:67-68, 89; Boucher 1973:55, 57.

4 Smuts 1960:8-9. 
professors did not focus on Greek and Latin only, but were often required to teach a range of subjects that were not necessarily related. ${ }^{5}$

The Cape University, founded in 1873 and recognised by Royal Charter of Queen Victoria, was an examining institution modelled on the University of London which had been established in 1836. Other areas were represented on the Council of the Cape University: Natal (1897), Free State and Transvaal (1902); ${ }^{6}$ and the Huguenot College, Wellington, established in 1898 and incorporated into the Cape University in 1907. ${ }^{7}$ The situation was far from ideal. McKerron observes: 'The smaller institutions complained that they were swamped by the representatives from Cape Town and Stellenbosch. The meetings were held at Cape Town, and the members from the more distant colleges could not always afford the time to attend them'. 8

In 1894 the Victoria College (formed in 1887 from the earlier Gymnasium's Arts Department) at Stellenbosch, and in 1900 the SAC shed their preMatriculation classes in order to focus on higher education. ${ }^{9}$ After the Anglo-Boer War (1899-1902), other universities were created: Rhodes University College (1904): ${ }^{10}$ the School of Mines in Kimberley, replaced by the South African School of Mines and Technology in Johannesburg (1903), in turn being transformed into the University of the Witwatersrand (1921); ${ }^{11}$ the Transvaal Technical Institute, becoming the Transvaal University College (1910) and emerging as the University of Pretoria (1930); ${ }^{12}$ Grey College in Bloemfontein splitting into the Grey College School and Grey University College (1907); and the Natal University College

5 McKerron 1934:84-86; Smuts 1960:9.

6 McKerron 1934:92-93, 94; Boucher 1974:25-78.

7 McKerron 1934:93.

8 McKerron 1934:94. For details concerning the problems, rivalries and opposing views, see further Boucher 1973:80-111.

9 McKerron 1934: 19, 92; Smuts 1960:16; Boucher 1973:57-62; Du Toit \& Smuts 1979:315-28.

$10 \quad$ McKerron 1934: 93; Boucher 1973:56.

11 McKerron 1934:93, 96; Boucher 1973:94-95. Boucher records a visit by the renowned Cambridge Classicist, Sir Richard Jebb, who, as a member of the British Association for the Advancement of Science, spoke in favour of the establishment of the University. Jebb emphasised the cultural influence, development of technical skills and cultivation of scientific habits of such an institution, but said nothing of the Classics specifically.

12 McKerron 1934:96; Boucher 1973:96-103. Pretoria and Johannesburg vied for this institution, especially when in 1906 the mining magnate, Alfred Beit, bequeathed $£ 200000$ for the erection of a 'University of Johannesburg' on his Frankelwald estate; 'Inventory of Beit Bequest Papers', Historical Papers Collection A576, p.1. University of the Witwatersrand (www.historicalpapers.wits.ac.za/inventory); Boucher 1973:97 (then converted to R400 000), 99, 111. 
being formed (1907). ${ }^{13}$ For Black students the choices were limited to the missionary colleges, which laboured under insufficient funds and facilities. The need was partially filled in 1915, when Alexander Kerr became Principal of the South African Native College at Fort Hare. ${ }^{14}$ In 1910 student numbers were low: around 300 each at the SAC and Victoria College, 125 at Rhodes University College, 113 at the SA School of Mines and Technology, 93 at the Transvaal University College, 73 at the Grey University College, 57 at the Natal University College, and 53 at the Huguenot College. ${ }^{15}$

With the formation of the Union of South Africa in 1910, it became apparent that nine or ten independent universities were not viable. Scholars such as Proff C E Lewis and W R Ritchie spent much of their time and effort in committees dealing with the question of federal or independent universities, and in endless debates on the language question of English or Afrikaans as the medium of instruction, debates which were aggravated by the divided attitudes to South African involvement in World War I. ${ }^{16}$ In addition, there were problems such as the delayed delivery of examination papers from England and the difficulty of attending meetings, given the means of transport - which at the time, one must recall, was almost entirely limited to trains. ${ }^{17}$ The debate of federal or independent universities culminated in the University Act of 1916, which made provision for the creation in 1918 of only three self-governing universities: Cape Town, Stellenbosch and the University of South Africa. ${ }^{18}$ In 1918, the University of South Africa embraced the others, thus replacing the University of the Cape of Good Hope which had performed this function..$^{19}$ The Huguenot College was not regarded as of sufficient status to be incorporated; in 1951 it became the Huguenot Missionary College, its remaining 60 BA students finally being absorbed into Unisa's Division of External Students. ${ }^{20}$ The Theologische School van de Gereformeerde Kerk at Burgersdorp was moved to Potchefstroom (1905) and became the University for Higher Christian Education in $1921 .^{21}$

\footnotetext{
13 Boucher 1973:18-19, 101-2.

14 Boucher 1973:54-55.

15 Boucher 1973:102-3.

16 Boucher 1973:112-41.

17 Boucher 1973:116. Rail travel was still in its infancy, constructed from 1892 onwards and covering routes between the harbour cities and the inland cities.

18 Boucher 1973:136-41; Du Toit \& Smuts 1979:336-37.

19 McKerron 1934: 85-88; Smuts 1960:7-10, 16-17, 24; Boucher 1973: 26, 36, 41 (photo of the Royal Charter), 57, 112-43, 166 (a list of the colleges); Naudé 1993:20.

$20 \quad$ Boucher 1973:166, 189, 262.

21 McKerron 1934:95-97; Boucher 1973:19.
} 


\section{The nature of CASA in 1908-1910}

We now know from the newspaper item discovered by Whitaker that there was an inaugural meeting of a CASA in Cape Town in 1908, that Prof Ritchie (SAC) gave the Presidential Address (confirmed by the entry in the 'Synopsis' of his diary), ${ }^{22}$ that papers were delivered by Prof G Robertson (Bloemfontein), Miss A S Bleby (Rondebosch), Dr G C Cillie (Franschhoek) and Adv J A Greer, and that the Honorary Secretary was J G R Lewis (Mowbray). Whitaker correctly points out that this evidence reveals the remarkable fact that the organisers of this event visualised an association of a united South Africa two years before the Union of South Africa was formed. He suggests that the general move towards a Union, which culminated in meetings of the National Convention in October and November 1908 and another in 1909, may also have stimulated the establishment of a national association. Whitaker notes the presence of a delegate from Bloemfontein, then capital of the Orange River Colony. This may have been unusual at the time and certainly something special, to give the meeting a 'national' flavour. What is also interesting is that the listed names represent a spread of professions: two Professors of Classics, two high school principals, ${ }^{23}$ an advocate with a Doctor of Laws degree and (presumably) a school teacher. Further entries in Ritchie's diary record meetings of the new association or its council in 1908 (25 September and 13 November), in 1909 (12 February, 10 September and 26 November) and in 1910 (15 April, 20 August and 23 September, an AGM). Ritchie's entry for 19 November 1910 notes that the Association 'seems moribund' and no further mention of the Association appears. ${ }^{24}$

A survey of the South African institutions of higher learning offering Classics in the years 1908-1910 reveals how small was the number of classical scholars. In this period there were only two at the SAC: C E Lewis, a former graduate of the SAC, Professor of Classics 1879-1917, teaching Classics and Mathematics and later also English ${ }^{25}$ and Ritchie, Professor of Classics 18821929. ${ }^{26}$ At the Victoria College there were three: Prof A E Armour, who taught Classics and English from 1907 to 1912; and Prof S A Macdonald who taught

22 Whitaker 2012:166.

23 On Miss Alicia S Bleby, Principal of Rustenburg Girls' High School, see Whitaker 2012:166 n. 4; at the time Cillie was Principal of the Franschhoek High School ; Smuts 1960:27.

24 Whitaker 2012:166.

25 Smuts 1960:15; Boucher 1973:57, 103.

26 Smuts 1960:15-17; Boucher 1973:57, 87, 103, 106-9, 176; Whitaker 2012:165. 
Latin from 1903 until 1917. ${ }^{27}$ The Chair of Greek was occupied from 1903 to 1943 by Prof C S Edgar. ${ }^{28}$

A few prominent students graduated in Classics in this period. Mr F P Hoogenhout (MA Classics, Victoria College, 1901), who left Classics for Law; ${ }^{29}$ Dr Cillie (mentioned earlier), who was Associate Professor of Classics from 1909, but in 1913 moved to the newly-established Faculty of Education; ${ }^{30} \mathrm{Mr} \mathrm{J}$ A Ross (MA, 1909), later Professor of Greek at the Grey University College. ${ }^{31}$ I would like to think that these students, with their teachers, were among those who attended the inaugural meeting of the first 'national' conference in 1908, as well as other meetings in the following years.

From the above discussion it appears that the first CASA started off with obvious enthusiasm, confidence and a good dose of idealism, and with more or less regular meetings. Smuts remarks that before 1918, when all university colleges were still part of the University of South Africa, teachers of Classics in the various colleges met more frequently. ${ }^{32}$ There was, however, a very small pool of persons to deliver papers, and the activities and audience were restricted to Cape Town. At the time there were also qualified classicists teaching at schools, and one can only assume that they knew about and perhaps attended the meetings of the Classical Association. Whitaker is justified in suggesting that the small number of classicists and the difficulty and expense of travel must have been factors that led to its early demise. There were, however, many other factors. The general picture that emerges is of a group of scholars from Britain and Holland performing a multitude of administrative tasks and teaching a multitude of subjects and courses, and consequently deprived of the time and energy required to do research and meet with fellow scholars. In addition, the inadequate library resources crippled research, with the result that the majority of students who wished to reach doctoral level had to go abroad..$^{33}$ Of these many chose careers in law, theology and medicine, a tendency which was still evident in the $1930 \mathrm{~s} .{ }^{34}$

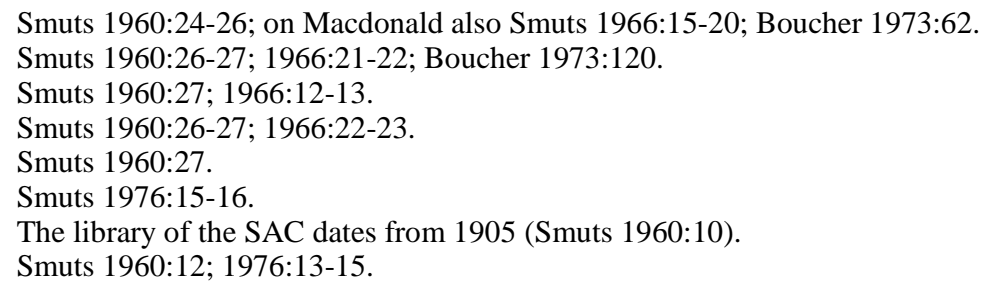


Classics in South Africa, 1911-1927

Many more teachers of Classics emerge on the stage after 1910. The Classics Department at the SAC was enlarged to three when Prof G W Vipan was appointed in 1911, and when he resigned in 1916, two lecturers replaced him: $\mathrm{Mr} \mathrm{J} \mathrm{H}$ Hofmeyr, who left in 1917 to become the first Professor of Classics at the South African School of Mines and Technology in Johannesburg, and Dr T le Roux, who was Professor from 1919 to $1948 .^{35}$ After the SAC became the University of Cape Town in 1916, Rev W A Norton was a lecturer for a brief period in 1919, and was succeeded in 1920 by Mr B Farrington, who held the Chair from 1930 to $1934 .^{36}$ Another lecturer, Mr C F K Watson (1922-1925), was succeeded by Mr W Rollo in 1926; he occupied the Chair from 1935 to $1952 .{ }^{37} \mathrm{Mr} \mathrm{S} \mathrm{J} \mathrm{H} \mathrm{Steven,} \mathrm{who} \mathrm{gained} \mathrm{his}$ MA at the University of Cape Town in 1921 and took a degree in Greats at Oxford in 1924, taught at the Universities of Cape Town and the Witwatersrand, before becoming Lecturer (1927), Senior Lecturer (1936) and Professor at the University of the Orange Free State (1941-1962). ${ }^{38}$

In the post-Union period at Stellenbosch, Prof Armour still occupied the Chair of Classics and English (until 1912), Prof Macdonald the Chair of Latin (until 1917) and Prof Edgar the Chair of Greek (until 1943). Dr P van Braam, who had come from Rhodes University College in 1913, succeeded Macdonald in 1917 and held the position until 1946. ${ }^{39}$ Edgar and Van Braam were the incumbent professors when the Victoria College became the University of Stellenbosch in 1918. Mr P Horsfall, an ex-student of the SAC, was lecturer in 1912, but left the teaching profession, ${ }^{40}$ while another ex-student of the SAC, Mr T J Haarhoff, taught for three terms at Stellenbosch before leaving for Berlin and Oxford and, from 1922, enjoying an illustrious career as Professor of Classics at the University of the Witwatersrand in Johannesburg. ${ }^{41}$ Rev J McCulla was lecturer from 1914 to $1931 . .^{42}$

35 Smuts 1960:18. On Hofmeyr, see also Boucher 1973:50, 162-63, 217, 220, 250, 276; Naudé 1993:20.

36 Smuts 1960:18-20; Atkinson 2010 and forthcoming (I am grateful to John Atkinson for sending me an advance copy of this article).

37 Smuts 1960:18, 20-22.

38 Smuts 1962; Boucher 1973:285, 306.

39 Smuts 1960:27-29; 1966:13, 23-25.

40 Smuts 1960:26.

41 Petrie 1958; Smuts 1960:26; McCleery 1968:i-ii; Titlestad 1974; Naudé 1993:19; Lambert 2011:46-49. A numbered list of Haarhoff's publications (with 494 items) was compiled by McCleery 1968; see also AClass 1 (1958):162-63.

42 Smuts 1960:26; 1966:25-27 (with an obituary by Edgar published in the Proceedings and Selected Papers of the Classical Association of S.A., $2^{\text {nd }}$ Issue, 1929-31:6). 
Three students who later made their mark on the Classics in South Africa graduated in 1911: Mr J J Basson (MA), who received a doctorate in Germany in 1917) and in 1918 was appointed to the Chair of Classical Philology which he occupied until his death in $1938,{ }^{43} \mathrm{Mr}$ Le Roux, mentioned above (Classics Honours); and Mr H G Viljoen (Classics Honours), who became Professor of Greek at Pretoria University in $1931 .{ }^{44}$

At the University of Natal, Prof A Petrie came out from Scotland to establish the Chair of Classics in $1910,{ }^{45}$ and in Johannesburg the South African School of Mines and Technology, established in 1903, only appointed a Professor of Classics in 1917, in the person of Hofmeyr, who was succeeded by Dr Le Roux in 1919. A promising young scholar, Mr A I Wagner, who had obtained a BA with Honours from the SAC in 1910 and a three-year scholarship from the Transvaal University College in Pretoria in 1911, proceeded to Oxford. On his return, he taught at the South African School of Mines and Technology, becoming Lecturer in 1920, only later to choose a career in law. ${ }^{46}$ The institution became the University of the Witwatersrand in 1921 and Haarhoff became Professor of Classics the following year.

The persons mentioned here represent the body of Classicists active in the years preceding the establishment of the second Classical Association of South Africa.

The Classical Association of South Africa: Stellenbosch Branch, 1927-1953

The first year, 1927

Attached to the first page of the Minute Book are the minutes of a meeting held at the University of Cape Town on Saturday, 26 March 1927 'for the purpose of founding a Classical Association of South Africa' [E]. ${ }^{47}$ The audience consisted of representatives of the Universities of Cape Town and Stellenbosch, and the Huguenot University College in Wellington as well as a number of students. It was decided to form the Association, which would meet annually to elect office bearers

43 Smuts 1960:27-29; 1966:27-30 (with an obituary by J A Wiid published in Die Stellenbosse Oud-Student April 1939).

44 Smuts 1960:27; De Kock 1987.

45 Steven 1959; Boucher 1973:101-2.

46 Naudé 1993:19.

47 The Minutes are referred to as either [E], written in English or [A], written in Afrikaans. Minutes were read and approved at all meetings except initial ones and those held for lectures only (22 August 1927, 5 July 1928, 18 July 1929, 20 August 1929, 12 October 1932 and 18 April 1933, 20 May 1952, 30 July 1952; Greek section: 19 September 1927). 
and deal with administration; meetings for lectures, discussions or other purposes would be organised by the Committee. The Committee was to consist of a President, Vice-President, Honorary Treasurer, two Honorary Secretaries and a representative from each local centre. A Publication Committee, consisting of the Treasurer, one Secretary and two other members, was also proposed to handle all the editing, printing and publishing of the Association. The Association was to be constituted as 'a federation of local centres', each independently managing its own affairs and organising its own annual programme. Membership of a local centre entailed membership of the Association and other centres, and had two categories: ordinary members who paid $2 \mathrm{~s}$. $6 \mathrm{~d}$., and junior or associate members who paid $1 \mathrm{~s}$ $6 \mathrm{~d}$. The Secretaries were to draft an annual report containing a financial report and resumés of the activities of each local centre for approval at the AGM and dissemination among members. Affiliation was to be sought with other Classical Associations, in particular those of England. The meeting then elected the following Committee members: the Hon. J H Hofmeyr (Hon. Pres.), the presidents of the local centres ex officio (Vice-Presidents), Prof Edgar of Stellenbosch (Hon. Treasurer), and Dr Rollo of Cape Town and Miss M V Williams of Johannesburg (Hon. Secretaries). The Publishing Commitee consisted of Dr Rollo (S) and Proff Smail of Grahamstown and Petrie of Pietermaritzburg.

In a brief paragraph as prelude to the report on the 'first national conference' of 1956, the editors of Acta Classica mentioned the 'first Classical Association' of 1927, naming its founders and the local centres. It was also pointed out that national conferences had been impracticable and that the Association virtually ceased to exist in the 1930s and that by 1956 only the Johannesburg Classical Association was still active. ${ }^{48}$

The Inaugural Meeting of the Stellenbosch branch was held on Tuesday, 9 August 1927 in the lower Latin classroom at the University of Stellenbosch [E]. The object of the meeting was to establish a Stellenbosch Classical Association as a branch of the Classical Association of South Africa. Thirty names appear on the list of those present: Proff Van Braam and Edgar; Messrs P J Roos, P J Loseby, ${ }^{49}$ J J Müller, J R Holzapfel, R A Jooste, T R Nel, H Thomson,

48 Editors 1958:164; Smuts 1966:10-53, 87; 1976:11-21; Henderson 2004:90 n. 4. Activities of the first three years (1927-1929) were surveyed in Proceedings and Selected Papers of the Classical Association of South Africa, $1^{\text {st }}$ Issue, Period 1927-1929 (Cape Town 1929). Smuts 1960:26 also mentions Prof Edgar's role in the foundation of 'the old Classical Association of 1927'. He refers to the second CASA again at 18 n. 49.

49 Classics teacher at the Boys' High School, Stellenbosch, who counted in his 1925 Greek class Messrs Notcutt and G Roos. See Smuts 1957:1-2; 1966:40. 
D J Kotzé, A H Jonker ${ }^{50}$ G S Möller, J L von Wielligh, H L Gonin, ${ }^{51}$ J S Erasmus, J C Cooper, J C Steijl, D Grundlingh, P J and J P J van der Westhuijzen, B Slabbert, C H Loubser, L E Smith and G T Minnaar; Misses C Nel, M du Toit, $\mathrm{R}$ van Blerk, $\mathrm{M}$ van Dijk and I de Jager. Prof Van Braam took the Chair and explained the importance of Classical studies and the aims of the new CASA. The meeting then agreed to constitute the Stellenbosch Classical Association 'as a local and autonomous branch' of CASA. Office-bearers were elected for 1927: Prof Van Braam (President), Messrs Nel and Müller (Joint Honorary Secretaries, Latin and Greek sections respectively), Prof Edgar (Treasurer), Mr Kotzé (Vice-President, Latin section) and Mr Jonker (Vice-President, Greek section). The Junior sections were to elect the other six members (three each for Greek and Latin) of the Committee. The association would hold combined meetings on Monday evenings at 19:00, the next one to be on 22 August, when Prof Van Braam would read a paper on 'The conception of guilt in Ancient Classical Tragedy'. Proff Edgar and Van Braam were requested to draft a constitution.

The first General Meeting duly took place on Monday, 22 August 1927 [A]. Prof Van Braam gave his talk, which covered the development of tragedy from Aeschylus to modern times. Prof Edgar disagreed with some of the speaker's views. The evening closed with the election of a Vice-President (Mr Jooste) and other committee members (Miss Van Blerk and Mr F S Crafford). On Monday, 12 September, the Latin Section met to listen to two papers: Mr Thomson on Stoicism, and Mr Kotzé on Roman women [A].

A week later, on Monday, 19 September 1927, the Greek section held its first meeting [A]. The committee members were officially confirmed as Mr Jonker (C), Mr Müller (S) and Messrs D Basson, Möller and Van der Westhuijzen (Additional Members). A paper by Mr Gonin on the ancient Olympic Games was then read by Mr Holzapfel as Mr Gonin had left for Oxford. After comments by Prof Edgar, the Secretary was charged with writing a letter of thanks to Mr Gonin as well as good wishes for his studies and athletics career. ${ }^{52} \mathrm{~A}$ second lecture was given, on Euripides' Ion by Mr Notcutt. Mr D Weiss opened the discussion to which Dr Basson also contributed. At the second meeting, on Monday, 10 October, 15 students attended along with the Chairperson, Secretary and Prof Edgar [A]. Two papers were read: Mr Van der Westhuijzen on 'The universities of ancient Greece', and Mr Möller on Greek pottery of the prehistoric period, accompanied by lantern-slides. After the discussion, the Chairperson thanked Prof Edgar for his

50 Dr Jonker, father of the poet Ingrid Jonker, embarked on a political career; see Boucher 1973:287.

$51 \quad$ Cf. Kriel 1971; Smuts 1975.

52 Strongest in the 100 and 440 yards events, he later won full colours at Oxford. 
efforts in establishing a Classical Association and for his interest in the students, and hoped that the Association would achieve great things.

The first AGM of the national Association took place at the end of the year. A published report in Afrikaans, found among the documents in the Minute Book, with unspecified source and date, is headed 'Die Studie van Klassieke Tale. 'n Agteruitgang wat betreur word. Jaarvergadering van die Klassieke Genootskap van Suid-Afrika' ('The Study of Classical Languages. Decline deplored. Annual Meeting of the Classical Association of South Africa') ${ }^{53}$ The first paragraph states that the meeting was held at the University of Cape Town, on 'last Tuesday', that Mr Hofmeyr (Hon. Pres.), Administrator of the Transvaal, ${ }^{54}$ took the Chair, that Sir John Carruthers Beattie was among those present, ${ }^{55}$ and that there were representatives from the universities of Cape Town, Johannesburg, Bloemfontein and Wellington. An Afrikaans summary of Mr Hofmeyr's presidential address takes up most of the report. Since the publication in which this report appeared is as yet untraced, and because it raises issues and expresses views that were to resonate repeatedly in future debates, I take the liberty of giving a lengthy survey of its contents.

Hofmeyr first explained the growth of the Association and then expanded on its aims: to provide a forum for those who studied Classical Antiquity to meet and exchange ideas; to promote the study of Classics and ensure it a worthy place in the educational system; and to encourage the public to appreciate the meaning and spirit of the classical languages, with their literary treasures, in order to contribute to South Africa's culture and, by learning lessons from the past, to solve present problems. Such an awareness of the past was part of our cultural history, 'a biology of humankind', from which, among others, our political ideas and systems of government were derived.

He proceeded to give an account of the declining figures for Greek and Latin at schools. Of the 2195 candidates who wrote the first Matriculation examinations of the Joint Board in 1918, 1933 (88\%) wrote Latin and 122 (5,5\%) Greek; in 1926, out of a total of 3484 candidates, 1941 (56\%) wrote Latin and 76 (2\%) Greek. Greek was clearly disappearing from the schools, while Latin was losing numbers to French and German (the latter impressed on the Afrikaans-

53 I am grateful to Jo-Marie Claassen (Prof Emerita, Stellenbosch), Anneke Schaafsma (J S Gericke Library, University of Stellenbosch), Ronel Smit (University of Johannesburg Library) and Natasha Chhiba (Research Assistant) for their assistance in trying to trace the source and date of this document. The minutes of the meeting have not yet resurfaced.

54 Mr Hofmeyr held this position in 1924-1929.

55 Sir John Carruthers Beattie was the first Principal and Vice-Chancellor of the University of Cape Town, 1918-1937. 
speaking children in rural areas as an easy language). The problem was as yet less serious at university level, with the standard of work in fact rising markedly, but the decline in schools would inevitably affect standards. In the minds of the public and educationists, increasingly focused on a more practical education, the Classics were regarded as a useless relic of a worn-out tradition.

In the final section of the speech, Hofmeyr admitted that classicists had erred in demanding too great a space for Latin in the syllabus and in making Latin compulsory. This had caused a back-lash against Latin from which it was now showing signs of recovering. The task of CASA should be to reposition Latin according to its relative value. This could be achieved by persuading and showing the public that the study of Classics was not just about dry grammatical exercises, but about every cultural aspect of Greek and Roman civilisation. Teaching at school should be as interesting and effective as possible and university teachers should advise and assist school teachers in their areas. He questioned the opinion that South Africans had no literary talent, for there were already indications that both English and Afrikaans literature would undergo great development in the near future. This made it all the more regrettable that the great source of inspiration of the Classics was being pushed aside. I translate his last sentence: 'All great literatures of Europe have drawn from the Classics and it would therefore be exceptionally arrogant if we wanted to prove that a nation that assigns no value to the literatures of Greece and Rome, can still produce a literature which would take its place alongside the great literatures of the world'.

The newspaper article concludes with a summary of the Secretary's report on the activities since the previous meeting in 1927. First there is mention of the foundation meeting on 26 March 1927, and of the constitution and aims of the Association. Then comes the information that the initial impetus for the formation of a Classical Association of South Africa came from a visit by Rev Dr C C Richards of Oriel College, Oxford, at the beginning of 1927. Next there follows a survey of the branches in other centres 'during the last nine months', which would place this meeting in December 1927 and date the newspaper report shortly afterwards. Nothing is added to what has been said above about the Stellenbosch branch. Details of the other branches are, however, worth recording here.

The Johannesburg branch took shape on 21 April 1927, at the University of the Witwatersrand, when a decision was made to transform the existing students' Classical Association into a branch of CASA. Prof Haarhoff (C), Mr L A Hudson (T) and Mr S Davis (S) were elected to the Committee. There were 58 members. The first lecture, before an audience of about 100, was given by Prof Haarhoff, on 'Rome then and now'. On 10 June Miss Williams read a paper on the religious 
background of Plato's philosophy, and on 16 September Mr H J Hofmeyr read one on Roman imperialism. ${ }^{56}$

The Cape Town branch was founded on 23 April 1927, with Prof Ritchie (C), Prof Le Roux (T) and Messrs Farrington and A Fox (S) on the Committee. It was decided to have one open (public) and one closed meeting per term. Prof Ritchie first gave a public lecture on Pompeii, followed by Prof Le Roux on the Acropolis, with lantern-slides. At closed meetings there was a plan to have two lectures, if possible. There were about 30 members, meetings were well attended, except for the latest one, and great interest was shown.

In Grahamstown there had already existed a local society since 1924, which now resolved to join the national Association. Branches were soon to be formed in Pretoria, Bloemfontein, Pietermaritzburg, Potchefstroom and Kimberley. On the Wellington branch nothing was reported..$^{57}$

Finally, the article reports the election of office-bearers for the next period: Mr Hofmeyr (Hon. Pres.), Prof Edgar (T), Miss Williams and Prof Rollo (S).

The second year, 1928

The Latin Section met again on Monday, 26 March 1928 [E]. The same committee members were elected, except for Mr Nel, who had left and was replaced by $\mathrm{Mr} \mathrm{B}$ Notcutt. Prof Van Braam reported on the proceedings of the General Meeting of CASA, at which the President, Mr Hofmeyr, had delivered an inspiring address. Acting on a suggestion by Prof Van Braam that students should take part in the discussion, Mr Thomson's proposal that two critics be appointed for each paper was accepted. Mr Crafford then read a 'long and learned' paper on Roman religion, tracing its evolution from the time of the kings, through the Republic and the influence of Eastern religions to Augustus.

The third meeting of the Greek section took place on Tuesday, 17 April 1928 [A], attended by 10 members and an unnamed visitor. The members elected to the new Committee were Mr Jonker (C), Mr P J van der Westhuyzen (S) and Mr J S Erasmus (T). A further three members were elected to the Committee: Prof Edgar, Dr Basson and Mr G Cronje. Mr Möller, continuing his presentation at the previous meeting, gave a fascinating, hour-long talk on Greek painted pottery of the Classical period which he illustrated with lantern-slides. During the

56 Smuts 1960:18 n. 49 mentions a paper delivered by Haarhoff to the 'Johannesburg Local Centre of the Class. Ass.' which was published in the Proceedings of the Classical Association of South Africa, $2^{\text {nd }}$ issue, 1931.

57 Smuts 1960:20 n. 51 draws attention to a paper read by Rollo to the 'Wellington Local Centre of Class. Ass.', published in the 1931 issue of the Proceedings, in Afrikaans: 'Primitiewe kultuur en die vroeë godsdiens van Griekeland'. 
discussion Mr Jonker suggested that the human figures in the geometric style were probably due to the shape of the vase. A fourth meeting was held on Tuesday, 15 May, when Mr J J du Toit took the Chair in the absence of Mr Jonker [E]. Mr P V Pistorius delivered a paper entitled 'Philosophy and religion in the drama of Euripides'. ${ }^{58}$

A General Meeting was held on Tuesday, 5 July [E]. Rev Loseby gave a learned and witty account of magic and its uses in the ancient world and the present: the recovery of faithless lovers, the recalling of departed spirits, metamorphoses, and the escape from the envy of the gods. His conclusion was that the purpose of magic was 'to solve the insoluble, avoid the inevitable, and make the dead behave' ${ }^{59}$ Prof Van Braam added Horace's treatment of Canidia in Satire 2.8.

The Latin Section met for the third time on Monday, 30 July [E]. With the departure of both Chairperson (Mr Kotzé) and Vice-Chairperson (Mr Jooste), Prof Van Braam took the Chair and Messrs Thomson and Loubser were elected in their places. Mr Notcutt gave a talk on the influence of Homer on Greece, Rome and the present. After the discussion it was decided that two shorter papers should be read at meetings.

Another General Meeting took place on Thursday, 30 August [E]. This meeting was attended by about 180 persons. Rev Loseby took the Chair for Prof Van Braam's paper on Pompeii, illustrated with lantern-slides. In thanking the speaker, Rev Loseby suggested 'that the municipality of Stellenbosch should have been brought to see what splendid public buildings were erected in ancient cities'.

The Latin Section met for the fourth time on Monday, 17 September [E]. Mr Van der Westhuijzen took the Chair for Mr Loubser's paper on the origin of myths from the anthropological and philological points of view, explaining, inter alia, sacrifice, taboos and oracles. Mr Smith criticised him for not being lucid enough, but Mr Cronje supported the philological approach and Prof Van Braam suggested that the conflicting theories of the origin of myths could be reconciled, while Prof Edgar suggested a comparison between Bantu and classical mythology. Prof Rollo attended the meeting. This was the last separate meeting of the Latin Section; henceforth meetings were of the Stellenbosch Association as a whole.

The Greek section met for the fifth and last time on Wednesday, 24 October 1928 [A]. The Chairperson apologised for the long delay since the previous meeting which was attributed to unavoidable problems and not to the committee's negligence. Mr Cronje read a paper on Greek athletics (illustrated with lanternslides). Mr Notcutt added the point that the Greeks strove more for the prize itself

58 Pistorius was later professor at the University of Pretoria. See Smuts 1976:17-18.
59 Lee Loseby 1928. 
than for the victory and Prof Van Braam noted how for a Greek athletics was a religious commitment.

The second AGM of the national CASA was held in Cape Town on 7 December 1928. On this occasion Mr Hofmeyr delivered an address entitled 'The achievements of Roman imperialism' ${ }^{60}$

The third year, 1929

The Stellenbosch Association as a whole met on Monday, 25 March 1929 [E] at what seems to have been the first AGM. The Chairperson, Mr Thomson, briefly outlined the objectives of the Association. Prof Edgar's motion that the Latin and Greek sections should be merged, was adopted unanimously. The new Committee consisted of Mr Loubser (C), Mr Van der Westhuijzen (VC), Mr G D Roos (S), ${ }^{61}$ Prof Edgar ( $\mathrm{T}$ ), Mr Pistorius and Mr Crafford (Additional Members). It was decided that meetings should, as far as possible, take place on Tuesday evenings. Prof Edgar then read a letter from the Wellington branch concerning a performance of the Agamemnon. The incoming committee was tasked with arranging a possible repeat performance in Stellenbosch. The following meeting took place on Thursday, 2 May [E]. Prof Van Braam was re-elected as Chairperson of the Senior Section. Prof Theo le Roux of UCT then delivered a talk on the Minoan civilisation to a packed hall. The talk was illustrated with lantern-slides, in particular of the excavations at the Palace of Minos.

At the next meeting, on Tuesday, 14 May [E], Prof Edgar reported on the financial position and expressed the meeting's sympathy with Dr Basson who had had to take leave because of ill health. Mr Notcutt read a paper on the political aspect of Plato's Republic. When the Association next met, on 4 June [A], the decision to have two shorter papers rather than one longer one was applied for the first time. Mr T N Hanekom read a paper on the development of Roman drama, and Mr A K de Jager on the art of Terence. Two weeks later, on Tuesday, 18 June [E], Prof Edgar delivered the only paper, on Menander and New Comedy, in which he dealt with the development of comedy, the characteristics of Menander's style and the apparent immorality of ancient comedy. The last meeting of the year was held on Tuesday, 20 August [A]. While Mr Jonker took the Chair, Mr Loubser spoke on Vergil and Dante. Prof Van Braam complimented him on his clear

60 Atkinson (forthcoming) note 53. A portion of the address was published in Hofmeyr 1929 (kindly traced by Ms Schaafsma). No further documentation of this meeting has as yet come to light.

${ }^{61}$ Gideon Roos, later Head of the South African Broadcasting Corporation. 
exposition and the presentation of two portraits of Vergil, one through the eyes of the poet Dante, the other as a classical scholar. ${ }^{62}$

The fourth year, 1930

At the meeting held on Thursday, 13 March 1930 [A], in effect the second AGM, the Committee for 1930 was elected: Mr Loubser (C), Mr Roos (VC), Mr De Jager (S), Prof Edgar (T), Miss Wiid and Mr Cronje (Additional Members). An invitation from the Wellington Classical Association to join them in a debate was accepted and arrangements left to the Committee. Mr Roos then read a paper on the Orestes story in Greek literature.

At the next meeting, on Wednesday, 9 April [E], Mr Krige spoke on the influence of Seneca on English literature. On Monday, 19 May [A], in the absence of the Secretary, Mr Hanekom was elected as Acting Secretary, and Mr J S Coetzee took the Chair for Mr Loubser's paper on education among the Greeks. Prof Van Braam chaired the meeting on Tuesday, 17 June [A], when Mr Roos delivered a paper on classical education abroad, in particular the teaching of Latin in the Junior High School system in America. He showed copies of the textbooks and explained their effectiveness. He also touched on education in Europe. At the end of the meeting Mr Loubser proposed that the Wellington branch be invited to Stellenbosch for a debate. This was accepted.

The year ended with three meetings, two weeks apart: on Tuesday, 12 August [A], Mr Loubser welcomed Prof Farrington of Cape Town, who delivered a paper on Epicurus and his philosophy; on Tuesday, 26 August [A], Mr Hanekom gave a detailed account of Stoic doctrine, in which he also pointed out correspondences between Stoicism and Christianity; on Monday, 8 September [A], with Mr Hanekom in the Chair, Mr De Jager gave a talk on Etruria. Prof Van Braam added some remarks, especially on Etruscan art and its influence on the Romans.

The fifth year, 1931

The AGM, postponed from 31 March, was held on Tuesday, 14 April 1931 [A]. The following were elected on the new Committee: Prof Van Braam ( $\mathrm{C}$ of the General Association), Mr De Jager (C of the Junior Association), Mr P C Higgo (VC), Mr Coetzee (S), Prof Edgar (T), Messrs H L Joubert and Hanekom (AM). Prof Van Braam then presented a paper on Horace and his villas at Tibur, with a

62 A report on the proceedings appeared in the 1929 Stellenbosch University Yearbook and a report for 1930 was requested; Acting Registrar to G Roos, 18 November 1930. 
sketch of Horace's life and works, and illustrated with lantern-slides of the landscape; he also pointed out relatively modern characteristics in Horace's poetry.

At a meeting on Tuesday, 5 May [A], Mr De Jager gave a talk on Tiberius in which he highlighted positive aspects of Tiberius' reign. On Tuesday, 26 May, Prof Edgar gave a lecture on Prehistoric Greece, with special reference to the Early Minoan civilisations on Crete. The audience were supplied with charts with outlines and dates of the Aegean civilisations in Crete, the Cyclades, the Peloponnese, Central Greece and Thessaly. He then showed lantern-slides of the reconstructed plans of the palace of Knossos and a few relics of vases, stamps and frescoes to illustrate the way of life, customs and games of the people. He ranked a picture of three women among the world's artistic masterpieces. ${ }^{63}$

The next meeting fell on Tuesday, 11 August [A], when Mr Hanekom spoke on the Oriental religions in Rome. He first surveyed the ways in which the eastern religions reached Rome (trade, war, international relations) and then dealt with the provenance, nature and adherents of Magna Mater, Isis, Serapis and Mithras. He was complimented on the fact that he had talked to the audience instead of reading a paper, a method recommended to future speakers.

At the meeting on Tuesday, 25 August [E], Prof Edgar followed up his lecture at the meeting of 26 May with one on the Mycenaean civilisation. He referred to the migrations, the influence of Crete, the siege of Troy, and the destructive invasions of Dorians. The talk was followed by lantern-slides showing the ruins of Mycenae, Tiryns and Troy and a comparison between the art of Knossos and Mycenae. At the meeting of Tuesday, 8 September [E], the format of having two papers on the programme was followed. First, Mr F G van der Riet gave a talk on slavery in Rome which treated the organisation, duties, treatment and punishment of slaves, and the effect of slavery on the Romans. Then, $\mathrm{Mr}$ Higgo spoke on Roman roads: their construction, network and role in communications and transport. The last meeting of the year was held on Tuesday, 13 October [A]. On this occasion Mr Joubert gave a talk on the Acropolis in Athens, followed by a slide-show of the main Greek temples, with comments on their architecture.

Later in May, a 'Juniores' section of the Association was established to give students the opportunity of presenting papers. ${ }^{64}$

The national Association had met in June 1931. Prof Le Roux was elected as the new Chairperson, and Miss I M E Fremantle as Secretary. ${ }^{65}$

63 This must refer to the three 'Blue Ladies', c. 1500 BC, Herakleion Archaeological Museum, Crete.

${ }^{64}$ Van Braam, Stellenbosse Student, May 1931, quoted by Smuts 1966:39.

${ }^{65}$ Cf. Secretary's report of 20 January 1933. No further documentation has been traced. 
The sixth year, 1932

Only one meeting, evidently an AGM, took place in 1932, on Tuesday, 12 October [A]. With Prof Van Braam in the Chair, the meeting elected the following officebearers: Prof Van Braam (Honorary C), Mr De Jager (C), Mr J P J van Rensburg (S). Prof Farrington of Cape Town presented a paper entitled 'Plato, the man and his work'. ${ }^{66}$ In a draft report of the activities of June 1931 to November 1932, written in pencil in a hand not matched by any in the Minute Book, the notable number of lectures given by students in 1931 was highlighted. Also noted was the fact that no students gave lectures in 1932, when the only lectures given were by Prof Van Braam, in a series of three lectures under the auspices of the Classical Society as extension lectures of the University, and Prof Farrington's on Plato. Attendance at these lectures was 'very satisfactory'. The report continues: 'The interest shown by students and members of the public other than students of the Classics gives reason to be hopeful for a future of the Classics in Stellenbosch'.

Administration continued. Miss Fremantle, Secretary-Treasurer on the General Executive, sent a note to Van Rensburg, Secretary of the Stellenbosch branch, promising the despatch of 25 copies of the minutes of the previous General Meeting, and including the agenda for the next meeting; and requesting a report from the secretary and treasurer, and the names and addresses of the local executive.

The seventh year, 1933

On Friday, 20 January 1933, the Annual General Meeting of the national Association was held, this time at the South African Public Library in Cape Town. With Prof Le Roux in the Chair, the minutes of the previous General Meeting in June 1931 were read and confirmed. The Secretary, Miss I M E Fremantle, read a report on the activities for the period June 1931 to December 1932. After this, the Treasurer's report was tabled and accepted. The following motions were adopted:

1. That the control of the Association be vested in an Executive, consisting of a President, Vice-President, Secretary-Treasurer and one ordinary member, to be elected for a term of three years by the General Meeting;

2. That publications be in the charge of the Executive, which would have power to delegate any duties under this head to appropriate persons;

3. That the constitution be amended in accordance with these changes;

66 S-T to Van Rensburg, 18 November 1932. 
4. That the headquarters of the Classical Association of South Africa be situated in Cape Town;

5. That there should be one Honorary Secretary-Treasurer, resident in the Cape Province, who would act for the Association thoughout the Union;

6. That a General Meeting should be held every year in Cape Town during the summer vacation.

The following were elected as office-bearers: Prof Lewis (P), Prof Van Braam (VP), Miss Fremantle (S-T) and Dr Rollo (AM). The business meeting over, Prof Haarhoff delivered an address on 'Seneca the Younger'.

Miss Fremantle again sent a letter to Van Rensburg regarding the despatch of copies of the minutes of the previous AGM of CASA, the Secretary's and Treasurer's reports and 20 copies of the press report of Prof Haarhoff's address, and asking in turn for the names and addresses of the Secretary and Treasurer of the branch, and the number of additional members, including students. She also wished to know whether the students were junior members of CASA or organised into their own society. She intended to request this information from all the centres, since it had emerged that in some centres the students had formed Classical Societies outside CASA. The idea was to change the constitution to bring all such societies into the body of CASA, which existed for this very purpose. ${ }^{67}$

The AGM of the Stellenbosch branch was held on Tuesday, 18 April 1933 [A]. The Chairperson, Prof Van Braam, remarked that the year 1932 was not exactly one that did credit to the Association and its management. The Secretary, for example, had only been chosen in October. He explained that as a consequence his term of office had been too long and expressed the wish that someone else be elected. He proposed Dr Gonin, a former student at Stellenbosch. This was accepted, and the following office-bearers chosen: Mr Van Rensburg (VC), Mr H L Swanepoel (S and T) and Mr Loxton (AM) ${ }^{68}$ Dr Gonin then delivered an address on the Classics during the transitional period from the 4th to the 9 th centuries. The paper demonstrated that there was much more to learn about the Romans than Caesar. Prof Van Braam thanked the speaker for the way in which he had covered such a long period, for the insight into the political circumstances of the time, and for ascribing the decline of the Roman Empire to economic factors rather than the barbarian invasions.

67 S-T to Van Rensburg, 12 March 1933.

${ }_{68} \mathrm{~T}$ postcards to Swanepoel, 13 and 15 November, explaining payments to be made to the branches; subscription receipt to Swanepoel, 12 December 1933, for $£ 8-6$. 
At the only other meeting of the year, on Tuesday, 16 May [A], Dr Gonin welcomed Prof Rollo of Cape Town, who then addressed a large audience on Ostia, Rome's harbour, illustrated with lantern-slides. He is recorded as having transported the audience on his journey to the present and the past Ostia. He mentioned that there was not much literature on the harbour, a state of affairs that would, no doubt, be rectified by the archaeological excavations. He dealt with the importance of the harbour, its growth into the largest harbour under Trajan, its decline from the 3rd century until Constantine's removal of municipal rights in 313. After Dr Gonin had thanked the speaker, Prof Van Braam added his compliments to Prof Rollo, a Scot, on his excellent Dutch. Much less enthusiasm greeted the Chairman's reminder that subscriptions were due.

The eighth year, 1934

The Annual General Meeting of the national Association was held on Friday, 18 January 1934, at the South African Library in Cape Town. With Prof Lewis (Hon. Pres.) in the Chair, Mr Hofmeyr, Minister of Education and of the Interior, delivered an address on 'The evolution of the civil service in classical times' ${ }^{69}$ This was followed by a business meeting..$^{70}$ The Cape Times reported the event and printed Mr Hofmeyr's address under the headlines (in capitals and decreasing fontsize): 'How civil service was evolved / Birth in turmoil of Roman Empire / Lessons to be learned from Classical times'. Three paragraphs of summary in lower case and three different fonts followed, referring to the 'brilliant address', 'a comprehensive survey of the administrative methods of classical times', which provided 'much food for thought for the student of ancient and modern government'. ${ }^{71}$

Again March passed without an AGM of the Stellenbosch branch. When the Association next met, on Thursday, 18 June 1934 [A], Dr Gonin, in the Chair, proposed that at this first meeting a new Committee should be elected. The ViceChairperson, Mr Van Rensburg, conducted the meeting, and the following were elected to the Committee: Dr Gonin (C), Mr Van Rensburg (VC), Miss S Van Aardt (S-T) and Mr Joubert (AM). Dr Gonin proceeded to deliver a paper on the political, economic and social conditions in the early Empire, which he illustrated with lantern-slides. Another meeting took place on Wednesday, 12 September [E]. While the meeting was waiting for Prof Farrington to arrive from Cape Town, Prof

69 Hofmeyr 1934.

70 No copy of the minutes of this meeting, the last of the national CASA, has yet come to hand.

71 Cape Times, 19 January 1934. 
Notcutt talked about the Roman remains in Britain. ${ }^{72}$ Prof Farrington arrived at 20:00 and immediately gave his talk, 'Horses and slaves in Antiquity'. ${ }^{73}$ He pointed out that the use of horses for general labour was not known until the Middle Ages; in Antiquity slaves did the hard work; they became the work animals. He stated that the abolition of slavery was not due to Europeans becoming ashamed of the practice, but because more profitable means of exploiting riches had been discovered. He also touched on slavery in America and on the Roman road system. His presentation ended with a lantern-slide show.

At the last meeting of the year, on Monday, 29 October [A], Dr Basson read a paper on Anti-Semitism in Antiquity. After a brief survey of Jewish history until the Diaspora during the reign of Hadrian, Dr Basson discussed aspects of Jewish culture that made them unpopular. Prof Van Braam expressed the Association's gratitude to Dr Gonin, who was to leave Stellenbosch that year, for his services over the previous two years.

The ninth year, 1935

The Stellenbosch AGM was held on Thursday, 16 May 1935 [A]. Dr Gonin was elected Chairperson, his departure for Pretoria having been delayed. The rest of the new Committee consisted of Mr Joubert (VC), Miss Van Aardt (S-T) and $\mathrm{Mr}$ Menty (AM). Prof Van Braam then gave a talk on Seneca and Stoic philosophy. He discussed Stoicism at Rome in the 1st century, its appeal to all classes and its main doctrines, and Seneca's brand of Stoicism. He situated him in the midst of a corrupt society, where he remained true to Stoic principles, and closed with remarks on Seneca's influence on the Romans and in the Middle Ages.

At the following meeting, on Tuesday, 18 June 1935 [E], Prof Edgar addressed the audience on the origin of Greek and European drama. He first traced the rise of drama from primitive masquerades with their religious nature, choral dances and dialogues in honour of Dionysus. He moved on to the introduction of an actor by Thespis of Attica in $560 \mathrm{BC}$, the introduction of masks to differentiate the characters portrayed by the single actor, and the break from the tradition of Dionysian cult which enabled all of Greek mythology to become material for

72 The Stellenbosche Student of August, 1934:144 reported that Notcutt had been welcomed at the University of Stellenbosch where he was to teach for six months. He had pursued his studies at Oxford, California and Harvard and received a doctorate from Stellenbosch University in 1935, after which he became Professor of Psychology at the University of Natal (Durban), where he died in 1953. For a tribute, see Yule 1953.

73 Reported on by 'B.N.' (sc. Bernard Notcutt) in Die Stellenbosche Student, October 1934, vol. 35 (6):252-53, with additional comments by Notcutt on the "native population' in South Africa (traced by Ms Schaafsma). 
drama. He closed with a discussion of how Aeschylus, Sophocles and Euripides advanced the development of drama. The lecture was followed by a lantern-slide show.

The last meeting of the year took place on Saturday, 14 September [A]. Dr Gonin spoke on Roman marriage to a large and interested audience. After an introductory survey of Roman history Dr Gonin dealt with the sources, various forms of marriage, requirements for a marriage, arrangements, the ceremonies, the meaning of marriage to women, Roman attitudes to marriage, and divorce. Passages from Latin literature were cited to illustrate the discussion.

This was the last meeting of the Stellenbosch Association for 17 years. When the Minute Book resumes it is May 1952, with new players. Various reasons for the collapse of the Association spring to mind. The Depression of the Thirties and the Second World War certainly feature in the wider context. Another, narrower context was the rising resistance to the classical languages (Greek had all but vanished from schools by 1930) and pessimism about their future. ${ }^{74}$ The more immediate cause was probably the vacuum left by the two dominant figures who had regularly given talks and taken part in the discussions. Prof Edgar retired in 1943 and died in 1945, Prof Van Braam retired in 1946, Dr Gonin moved to Pretoria in 1937 and Prof Basson died in 1938. It was left to their successors to rekindle the flame: J P J van Rensburg, Lecturer from 1939 to 1943, Senior Lecturer from 1944 and Professor in Classics, 1947-1976; Dr P J Rabie, Lecturer before leaving in 1948 to become a lawyer; Dr F Smuts, Lecturer in 1947 and Professor in 1951; Ms L Baumbach, Junior Lecturer, who left for Cambridge in 1955; A M Hugo and P J Conradie, assistants and after doctoral studies in Holland, Senior Lecturers in 1958; and Ms S Fitzpatrick, assistant. ${ }^{75}$

In Cape Town, Prof Rollo, who held the Chair of Classics from 1935 to 1952, organised informal but irregular meetings and discussions between members of the Classics departments of the Universities of Stellenbosch and Cape Town from 1948. ${ }^{76}$ Rev McCulla died in 1931, and Prof Farrington retired in 1934, Prof Le Roux in 1934.

Of those whose names appear in this account - the active participants, the speakers, debaters, office-bearers - most went on to pursue careers outside

\footnotetext{
Smuts 1976:14-15.
}

Smuts 1960:29-30.

76 Smuts 1960:21-22; 1976:15. In his account of Rollo's contribution to Classics, Smuts records Rollo's role in the foundation of the 'first' CASA, and his being an Honorary President of 'the newly constituted Association'. Smuts then adds: 'At a time when there was no Classical Association in existence it was of incalculable influence to stimulate interest, especially for the younger members, who sometimes felt themselves isolated in a large country such as South Africa, with centres of learning far from one another'. 
Classics. In theology there were Proff J J Müller (MA 1926), H L N Joubert (MA 1931) and T N Hanekom (MA 1932); ${ }^{77}$ in law Prof H L Swanepoel (Latin III 1933); in education Messrs R Jooste (MA 1926), F S Crafford (MA 1927), CH Loubser (MA 1929), A K de Jager (MA 1931), P C Higgo (Latin III 1931); in politics A H Jonker (MA 1927); in broadcasting G Roos (BA 1929); in other academic disciplines G Cronje (MA 1929; sociology, drama); and in other fields Messrs F G van der Riet (Latin III 1931, librarian) and G T Minnaar (Latin III 1928, publishing). ${ }^{78}$

The Association showed signs of decline in the decreasing number of meetings over the nine-year period: 1927 (3 in two months), 1928 (5), 1929 (6), 1930 (7), 1931 (7), 1932 (1), 1933 (2), 1934 (3), 1935 (3). Even at the start there appear to have been administrative problems; it took a year before a fixed programme and a more or less regular AGM were in place; there was no 'official AGM' until 1929 and the branch failed to adhere to a programme of annual general meetings.

There are, however, a few positive aspects: the lively discussions, especially from Proff Edgar and Van Braam; the participation of students on the committees, in the debates, as speakers and thankers of speakers, ${ }^{79}$ and the interchange of lecturers between Cape Town and Stellenbosch. ${ }^{80}$ There was also some coverage in the print media: in the Association's Proceedings and national and student newspaper reports. Smuts mentions the interesting and lively meetings attested by the 'old Minute Book', but also the waning interest until the branch ceased to function by 1936, with sporadic societies subsequently appearing and disappearing. ${ }^{81}$

\section{Resuscitation, 1952}

The minutes of Tuesday, 20 May 1952 are entitled 'Meeting for the reestablishment of the Classical Association at the University of Stellenbosch' [A]. The aim is stated: 'to found a Classical Association again'. The minutes mention, 'as a matter of interest', that the last meeting of the 'old' Association took place on 14 September 1935 and that Dr Gonin addressed the audience on Roman marriage. Dr Smuts welcomed the 20 persons present, explained the aims of the Association

77 Hanekom subsequently wrote a brief history of the Theological College at Stellenbosch; see Hanekom 1979.

78 See further Smuts 1966:47-52.

79 Smuts 1966:26, referring to the Proceedings, gives a brief account of the 1927 Association in which he records the involvement of students in its activities.

${ }^{80}$ According to Smuts 1966:22 Edgar also gave talks in Cape Town and Wellington.

81 Smuts 1966:39-41. 
and the need to develop an active membership. Dr Van Rensburg then expressed the wish that the students would also take part in the discussions. The Committee for the next year was elected: Ms Baumbach (C), Mr J van Zyl Steyn (Latin III 1953) (S) and Ms Fitzpatrick and Mr J A Wiid (AM). It was decided that meetings should be held on Wednesday evenings at 20:00.

The next meeting was held on Wednesday, 4 June [A]. Prof Van Rensburg gave a talk on translating Homer's Iliad. After an introduction on the background to Homer, he discussed the problems of translating Homer's epic, such as the impossibility of doing justice to the Greek hexameter. As examples, he read passages of translations in other languages (e.g. Matthew Arnold's), pointing out the difficulties. He concluded with his own Afrikaans version, demonstrating the difficulties of finding the right words, and reading extracts. Prof Smuts, asked to thank the speaker, observed that the directness and simplicity of Van Rensburg's translation was itself a work of art and worthy of the original. To a question from the audience Prof Van Rensburg replied that it would be impossible, or at least very difficult, to replace the Greek proper names with Afrikaans ones, since the sonority of the Greek would be lost. ${ }^{82}$

The Association's next meeting deviated drastically from the normal format. On Wednesday, 30 July Prof Van Rensburg hosted the gathering at his home [A]. The Greek and Latin students faced off in a quizz, with Prof Smuts asking the questions. On the Greek side were inter alia Mr W Hosten (Latin III 1952, later Professor of Law, Unisa) and, on the Latin side, Mr H W Rossouw (Latin III, Greek III 1953, later a philosopher). ${ }^{83}$ The Romans won narrowly and all were treated to tea and cake by Mrs Van Rensburg. The lecturers were then crossquestioned by those present.

For its next meeting, on Wednesday, 20 August 1953, the Association reverted to its traditional format. Mr Wiid read a paper on the origin and development of drama, in which he commented on the festivals of Dionysus, Thespis, Phrynicus, satyr-plays, Aeschylus' contribution, the structure of a tragedy and the theatre building before dealing with comedy (its origins, tone and organic growth, the phlyakes, Old Attic comedy and Aristophanes). Ms Fitzpatrick thanked Mr Wiid, congratulating him on a lucid exposition of a difficult subject and assuring him that it was most interesting and informative.

At the meeting on Wednesday, 10 September, Mr C K Johnman addressed the audience on 'Ancient painting, 6th century BC to the 12th AD.' His talk took

82 It is interesting to note that Richard Whitaker has just published an English translation of the Iliad in which he replaces Greek proper names, and also other parts of speech, with inter alia Xhosa and Zulu equivalents: The Iliad of Homer: A Southern African Translation (Cape Town 2012); see www.southernafricaniliad.com.

83 Smuts 1966:48, 50. 
the form of a running commentary on a series of lantern-slides he had taken on a recent visit abroad.

The final meeting of the year took place on Wednesday, 1 October [A]. In a lecture on Aeschylus' Oresteia, Prof Van Rensburg gave some background to Greek drama and proceeded to relate the plots of the trilogy and offer comments on particular aspects.

\section{Demise, 1953-1956}

At the AGM, held on Wednesday, 1 April 1953 [A], the following Committee was elected: Ms Fitzpatrick (C), Mr J Z Uys (S) and Mr Rossouw (AM). Ms Fitzpatrick then gave a talk on the need for the study of the Classics, in which she highlighted some materialistic and idealistic reasons for studying the Classics, ending with the final motivation: a love of the Classics for their own sake.

A larger audience attended the following meeting, on Wednesday, 29 April [E]. Ms Baumbach took the Chair in the absence of Ms Fitzpatrick and introduced the speaker of the evening, Mr H Hewitt of Cape Town University. His talk was entitled 'Excavations under the St Peter's Church in Rome' and consisted of comments on lantern-slides. After some questions, Mr Johnman moved a vote of thanks. The minutes record: 'Then the speaker was also given a good clap'. A silver collection was taken at the door to cover expenses.

A meeting on Thursday, 11 June, again took the form of a quizz, this time between teams from the Classics and English departments [A]. The English team consisted of Mr Newton-King, Miss Conradie and Mr Harvey, the Classics team of Messrs Smit, Heyns and Dicey. The Classics team won 22-17. The participants and lecturers adjourned to the Panorama for tea and ice-cream.

When the Association next met, on Thursday, 25 August [A], only 6 persons attended. Mr J van der Merwe, a teacher at the Paul Roos Gymnasium, spoke on 'The death-bed of Latin'. His decisive and witty account kept the audience spell-bound. Ms Fitzpatrick expressed her appreciation to the speaker and remarked that, for her part, he could have continued speaking.

The Classical Association of Stellenbosch held its final meeting on Thursday, 29 October, in the English Room [A]. Only a few attended: the Chairperson, the Secretary, three speakers and Prof Van Rensburg, and four others who signed the attendance list: $\mathbf{J}$ van der Linde, G J van der Westhuizen, H Muller and N Snijman. Three speakers related what the Classics meant to them personally: Messrs Rossouw (Greek III, Latin III), Smit (Latin III) and F Brand (Greek III). Here the Minute Book abruptly stops, without giving reasons for or in any way explaining the Association's decline and closure. 
Two notices bear witness to subsequent attempts to revive interest. The first notice, signed by $\mathrm{Mr}$ Uys, is for a public lecture organised by the English Department and desiring the support of members of 'the Classical Society'. The speaker was to be Prof H C Baldry of Cape Town on the subject of 'Some modern versions of Greek drama'. The meeting was set for Thursday, 28 May (year not given, but established as 1953). This was to be preceded by a preparatory lecture by Mr A Ravenscroft of the English Department on the Oresteia of Aeschylus. The other, also signed by Mr Uys, invites all interested persons and Classics students to a meeting 'of the earlier Classical Association' on Tuesday, 27 September (year not given, but falling in 1955), in the English Room. On the agenda were a discussion whether there is a specific need for studying the Classics, consideration of a proposal by Ms Fitzpatrick for a name-change, and the election of the Executive for 1956. The Secretary was still Mr Uys, elected in 1953.

\section{Conclusion}

When in 1976 Smuts again referred to the establishment of 'the old' CASA, its founders and its short-lived existence, he dwelt longer on the isolation of classical scholars, the lack of contact with colleagues in other centres (apart from the meetings of the southern branches initiated by Rollo) and the absence of a unifying body until the reconstituted CASA in 1956, which he saw as the culmination and maturation of a long process. ${ }^{84}$ It is clear that meetings of this second CASA were restricted to specific centres and that it was a 'national body' in name only. There was clearly activity in the Stellenbosch, Cape Town, Wellington and Johannesburg branches. Reasons for this lack of a unified body and national conferences must include, firstly, the sparse population. Although South Africa was eight times the size of England and Wales together, and the Free State four times that of the Netherlands, the census of 1921 revealed a population density of nearly 33 times smaller than that of the UK in 1921 and more than 36 times smaller than that of the Netherlands in $1920 .^{85}$ Secondly, there were the long distances between the universities at a time when such travel was difficult and costly, with only a few train services, limited private ownership of cars, and bad roads. ${ }^{86}$ Associated with this was, thirdly, the limited income of academic staff and lack of university funding in the period during and after World War I, and during the Depression of the 1930s. Circumstances and the whole educational context were simply not conducive to a stable and sustainable association.

\footnotetext{
84 Smuts 1976:17.

85 McKerron 1934:13.

86 McKerron 1934:13-14.
} 
This account is incomplete and should not end here. The minutes of other Annual General Meetings of the 'national' Association, as well as of the meetings and activities of the other centres need to be found and recorded. The contribution to Classics of the other centres of higher learning during this period of development of CASA (Wellington, Grahamstown, Bloemfontein, Johannesburg, Pretoria) needs to be researched and written up.

\section{BIBLIOGRAPHY}

Atkinson, J 2010. Benjamin Farrington: Cape Town and the shaping of a public intellectual. SA Historical Journal 62.4:671-692.

Atkinson, $\mathrm{J}$ (forthcoming). Benjamin Farrington and the science of swerve. In G Parker (ed.), Azanian Muse.

Boucher, M 1973. Spes in arduis: A history of the University of South Africa. Pretoria: Unisa.

De Kock, E L 1987. H G Viljoen [in Afrikaans]. In C J Beyers and J L Basson (edd.), Suid-Afrikaanse Biografiese Woordeboek. Part 5, 895-896. Pretoria: Human Sciences Research Council.

Du Toit, P S \& Smuts, F 1979. Kollege en universiteit. In Smuts 1979:325-342.

Editors 1959 [1958 on the cover and spine]. A report on the Classical Association of South Africa, 1956-1957. AClass 1:164-169.

Editors, 1974. Professor Alexander Petrie. AClass 17:9-10.

Hanekom, T N 1979. Teologiese Kweekskool. In Smuts 1979:315-323.

Henderson, W J 2004. The Classical Association of South Africa: April 1956January 1961. Akroterion 49:89-109.

Henderson, W J 2005. The Classical Association of South Africa: February 1961July 1966. Akroterion 50:109-123.

Henderson, W J 2006. The Classical Association of South Africa: July 1966January 1971. Akroterion 51:135-156.

Henderson, W J 2007. The Classical Association of South Africa: January 1971 January 1975. Akroterion 52:99-114.

Henderson, W J 2008. The Classical Association of South Africa: January 1975 January 1979. Akroterion 52:99-114.

Hofmeyr, J H 1929. Open horizon. Speeches and addresses delivered by Jan H Hofmeyr, 14-16. No publisher.

Hofmeyr, J H 1934. The evolution of the civil service. Cape Times 19 January. Kriel, D M 1971. Curriculum vitae. In D M Kriel (ed.), Pro munere grates. Studies presented to H L Gonin, 217-218. Pretoria: University of Pretoria.

Lambert, M 1911. The Classics and South African Identities. London: Bristol Classical Press. 
Loseby, P J 1928. Hecate and moonshine. Die Stellenbosse Student 29.5 (August):186-188; continued 29.6 (September):232-236.

McCleery, C S 1968. The works of Theodore Johannes Haarhoff. Thesis in part fulfilment for Diploma in Librarianship. Johannesburg: University of the Witwatersrand.

McKerron, M E 1934. A history of education in South Africa 1652-1932. Pretoria: J L Van Schaik.

Naudé, C P T 1993. The Department of Classics at Wits - a retrospect. Aquae Candidae. Epistula Witwatersrandensis 3:19-22.

Petrie, A 1958. Professor T J Haarhoff — an appreciation [in Latin]. AClass 1:9-20.

Smuts, F 1957. Ex epistulis. NL 2.1:1-4.

Smuts, F 1960. Classical scholarship and the teaching of Classics at Cape Town and Stellenbosch. Acta Classica 3:7-31.

Smuts, F 1962. In memoriam: Professor S J H Steven. NL 7.3:1-2.

Smuts, F 1966. Die Klassieke op Stellenbosch. Newsletter 11.3:10-53, 87.

Smuts, F 1976. Die Klassieke in Suid-Afrika 1930-1976. Akroterion 21.4:11-21.

Smuts, F 1975. Henri Louis Gonin - 'n waardering. AClass 24:x-xiii.

Smuts, F (ed.) 1979. Stellenbosch Drie Eeue. Stellenbosch: Stadsraad.

Steven, S J H 1959. Professor Alexander Petrie - joint Honorary President of the Classical Association of S.A. AClass 2:7-10.

Titlestad, R M 1974. A double tribute to Professor Alexander Petrie. AClass 17:18; Editors 1974.

Whitaker, R 2011. A Classical Association of South Africa in 1908. AClass 54:177-179.

Whitaker, R 2012. A further note on the first Classical Association of South Africa 1908-1910. AClass 55:165-167.

Yule, E. Pratt 1953. Bernard Notcutt: A tribute. Theoria 5:7-8. 